\title{
Instrumental Philanthropy, Nonprofit Theory, and Information Costs
}

\author{
${ }^{1}$ Austin W. Marxe School of Public and International Affairs, Baruch College, New York, NY, USA, E-mail: \\ george.mitchell@baruch.cuny.edu \\ ${ }^{2}$ Robert F. Wagner Graduate School of Public Service, New York University, New York, NY USA, E-mail: \\ thad.calabrese@nyu.edu
}

\begin{abstract}
:
Instrumental philanthropy has gained attention and popularity in recent decades as an approach to maximizing the impact of giving. This article evaluates the suitability of the nonprofit institutional form, specifically the US public charity, as a vehicle for instrumental philanthropy. The analysis identifies an incongruity between the informational requirements of instrumental philanthropy and the form and theory of the nonprofit. An alternative theory of licensure is proposed to illustrate the difficulty of the information problem. Analysis suggests that the viability of instrumental philanthropy hinges upon information costs. Several public policy options are considered as means of better supporting instrumental philanthropy, presuming that allocative efficiency in the production of public benefits is a desirable public policy objective.
\end{abstract}

Keywords: information costs, institutional design, instrumental philanthropy, licensure, nonprofit theory

DOI: 10.1515/npf-2019-0050

Instrumental philanthropy has emerged as a promising approach for increasing the social and environmental impact of individual philanthropists and of the nonprofit sector overall. Its object is to maximize the production of social outcomes given finite philanthropic resources by identifying and supporting the most cost-effective solutions. Although not necessarily a new approach, recent decades have seen significant innovations in institutional forms and instruments related to instrumental philanthropy in the United States and elsewhere. Governments, businesses, foundations, and other philanthropic actors have experimented with "payment by results" (Clist 2018) "pay for success" schemes, ${ }^{1}$ outcome funds, and social impact bonds (Gustafsson-Wright and Boggild-Jones 2018; Tekula and Andersen 2018), and newer generations of philanthropists, impact investors, and social entrepreneurs have expressed greater interest in data and impact (Goldseker and Moody 2017; Henderson 2014; Meehan III and Jonker 2018).

Instrumental philanthropy assumes many forms, including effective altruism (MacAskill 2017, 2016; Singer 2017), strategic (Brest 2015) or outcome-oriented philanthropy (Brest 2012; Twersky and Grange 2016), intelligent philanthropy (Schmidt 2014), smart giving (Weinstein and Bradburd 2013), investing in results (Bartlett et al. 2017), and value for money (BOND and ITAD 2012). It employs distinctive methods to account for outcomes, such as cost-effectiveness analysis (CEA) (GiveWell 2017), benefit-cost analysis (CBA) (Weinstein and Bradburd 2013), disability- or quality-adjusted life years (DALYs or QALYs) (Murray and Lopez 1990), social return on investment (SROI) (Emerson, Wachowicz, and Chun 2000), and the best available charitable option (BACO) (Acumen Fund Metrics Team 2007), among others.

Because instrumental philanthropists are outcome-maximizing, they will always prefer resource allocations that correspond with higher levels of aggregate outcomes, given their preferences and mission valence. ${ }^{2}$ Such philanthropists thus require relevant and credible information to inform decision-making (Henderson 2014; O'Flanagan, Harold, and Brest 2008; Ottenhoff and Ulrich 2012), particularly concerning the unit costs of program outcomes (Mitchell 2014). To facilitate this, various information intermediaries have sought to create online digital platforms to make outcome data more easily accessible (e. g. GuideStar Platinum) and to provide philanthropists with recommendations based on cost-effectiveness information (e. g. ImpactMatters, GiveWell). However, such efforts are relatively nascent (Ottenhoff and Ulrich 2012) and critical components of the information ecosystem required to support instrumental philanthropy remain under-scaled or absent (Schmidt 2014).

In the United States, where instrumental philanthropy represents a small fraction of total philanthropic giving, interest in this approach appears to be growing. ${ }^{3}$ Although its philosophy and methods have been the subject of pushback and criticism, ${ }^{4}$ instrumental philanthropy nevertheless potentially accounts for many tens of billions of dollars in annual individual giving in the US alone, comprising a relatively modest yet still significant pool of resources. ${ }^{5}$ 
Historically, the dominant institutional vehicle for philanthropic activity in the United States has been the 501(c)(3) public charity, or more simply, the "nonprofit". This article critically examines the suitability of this institutional form, including its regulatory environment, for instrumental philanthropy and considers implications for nonprofit theory and public policy.

The article is organized as follows. The next section examines the role of information in nonprofit theory, specifically in contract failure theory. The subsequent section derives an alternative theory of licensure, illustrating difficulties with the information problem. This is followed by a discussion of information costs. A further discussion about public policy considerations precedes the conclusion.

\section{Theoretical Context}

The institutional form of the nonprofit in the United States, the public charity, is defined by tax-exemption eligibility criteria and an illustrative list of permissible purposes specified in section 501(c)(3) of the United States Internal Revenue Code (IRC). Eligibility criteria prohibit private benefit, private inurement, and electioneering, and limit legislative activity. Acceptable exempt purposes include "religious, charitable, scientific, testing for public safety, literary, or educational purposes, or to foster national or international amateur sports competition ..., or for the prevention of cruelty to children or animals." 6 The "nonprofit sector" created by the IRC is extremely diverse, having expanded over time (Hall 2010). For example, the National Taxonomy of Exempt Entities adopted by the Internal Revenue Service (IRS) to categorize nonprofits recognizes 26 major groups and hundreds of sub-categories (Jones 2019). Although certain categories of nonprofits are subject to different regulatory requirements, they all generally operate under the same basic legal structure described by IRC Section 501(c)(3).

Organizationally, nonprofits in general have existed long before their codification in the US tax system. However, the modern form of the 501(c)(3) public charity was created largely by federal tax policies dating to the late nineteenth century (Arnsberger et al. 2008). Federal tax incentives were introduced in the twentieth century to encourage philanthropy (Arnsberger et al. 2008), especially for "lessening the burdens of government" (IRS 2018) through private voluntary action. Indeed, the "public good theory" - that the function of nonprofits is to provide public benefits that lesson the burdens of government - remains a popular justification for the sector's many tax advantages (Fricke 2015).

Scholars have suggested competing rationales for the existence of nonprofits, especially in the social services setting. Salamon (1987), for instance, posited that nonprofits exist to fulfill public needs and to essentially complement government services. Weisbrod (1988) observed a supplementary relationship for nonprofits, in which they provide services left unmet by government provision. Young (2000) has portrayed nonprofits as adversardescriptions about the nonprofit sector, but all tend to presume that nonprofits provide public benefits.

Not all nonprofits, however, aim to provide public benefits or to modify the burdens of government. For example, scholars have long supposed that nonprofits have both "instrumental" and "expressive" functions (Gordon and Babchuk 1959). As an instrument, a nonprofit may be regarded as "a concrete tool to achieve some collective purpose that society considers important"; its "instrumental value is measured in terms of its concrete outcomes" (Frumkin 2002, 23). As an expressive vehicle, "the very act of attempting to address a need or fight for a cause can be a satisfying end in itself, regardless of the ultimate outcome. The value that is created may be entirely psychic and may arise simply from the act of expressing commitment, caring, and belief" (Frumkin 2002, 23). Sector theories that portray nonprofits as filling service gaps neglected by the market and the government implicitly presume that nonprofits have at least some instrumental role in contributing to a public benefit. However, in practice many nonprofits may primarily or exclusively pursue expressive aims or serve the interests of their members rather than the public at large.

Hansmann $(1981 ; 1980)$ derived an expository typology of nonprofits. He distinguished between four "ideal types" - donative mutual, donative entrepreneurial, commercial mutual, and commercial entrepreneurial each representing a different pattern of income generation and control. However, he objected to efforts to categorize nonprofits and instead proposed a "unitary," broadly applicable theory of the nonprofit institutional form. His theory has provided the basis of most subsequent theorization, especially for economic theories of the nonprofit (Steinberg 1997).

Hansmann (Hansmann 1980, 1981) and also Weisbrod $(1975,1988)$ were particularly concerned about informational problems that arise when purchasers (such as donors or philanthropists) cannot accurately observe or evaluate their purchases. 7 Organizations stand to gain by exploiting this "information asymmetry" to engage in opportunistic behavior. For example, an organization could increase its profits by secretly reducing the quality of service provided to a third party. Anticipating this in advance, purchasers will refuse to contract 
with organizations to produce benefits that cannot be readily verified. This problem of "contract failure" is resolved by introducing the "nondistribution constraint," which prohibits the distribution of profits to those who control the organization. ${ }^{8}$ As the definitive feature of the nonprofit, the nondistribution constraint "blunt(s) the incentives for nonprofit mangers to take advantage of informational superiorities, since any additional profit obtained by capitalizing on such superiorities could not increase the income of nonprofit managers and directors" (Weisbrod 1988, 158). Purchasers thus "prefer nonprofits because that is the only way to be sure that contributions advance the stated goals of the organization rather than just increasing the profits of entrepreneurs" (Krashinsky 1986, 121). ${ }^{9}$ Additionally, this feature helps to screen out profit-seekers from entering the nonprofit sector in the first place (Young 2013; Steinberg 2006).

The nondistribution constraint imbues nonprofits with "trustworthiness," circumventing the contract failure problem (Hansmann 1980; Weisbrod 1988; Young 2013) and establishing nonprofits as preferred philanthropic intermediaries. ${ }^{10}$ The constraint provides donors and other purchasers with assurances that the organization will not sacrifice service quality for private profits. Hansmann (1996) characterized the nonprofit form as essentially a "crude but effective consumer protection device" that helps overcome contract failure. According to this view, "the primary function of a nonprofit is to serve as an organization that patrons can trust" (Hansmann 1981, 518).

However, the inability to observe the benefits or outcomes produced by nonprofits is not simply a problem of information asymmetry. If outcomes were observable, then contracts with for-profits would not fail and nonprofits would theoretically not be necessary. ${ }^{11}$ Purchasers could simply condition payments to for-profits upon outcome verification. The problem is that verification by any party is either impossible or prohibitively costly and therefore cannot be usefully undertaken. In other words, outcome information is wholly absent. ${ }^{12}$ For example, Weisbrod $(1988,53)$ notes that "certain activities are in the public or nonprofit sector largely because of the complexity of assessing them." Society specifically delegates the production of unobservable outcomes to nonprofits because of nonprofits' comparative advantage in trustworthiness. One important corollary is that nonprofits cannot be designed in such a way as to incentivize performance. Although some outcomes may have both observable (Type I) and unobservable (Type II) dimensions, "for such goods, it is more efficient not to reward performance at all than to reward only the Type I dimensions" (Weisbrod and Schlesinger 1986, 149).

Even if measurement was technically possible, it would presumably be too distortive to be worthwhile. Moreover, because performance cannot be measured or rewarded, in principle, a nonprofit could persist indefinitely simply by satisfying purchasers and without ever producing any intended outcomes. ${ }^{13}$ Weisbrod (1988, 52) summarized the dilemma as follows: "If we reward what we can measure, we distort behavior; if we do not, we discourage efficiency."

\section{A Theory of Licensure: Endogenizing Information Asymmetry}

Contract failure theory generally assumes that nonprofits sell unobservable benefits or outcomes to purchasers who are themselves unable to assess benefit quality. In a simplistic illustrative scenario, a donor contributes money to a nonprofit to produce a benefit for a third party, but no party can observe or accurately assess whether the benefit was produced or at what quality level. It is only because nonprofits are trustworthy (due to the nondistribution constraint) that such transactions take place at all. The efficiency reductions associated with the removal of the profit motive and the inability to reward effectiveness and cost-effectiveness appear to be unavoidable and so are not generally problematized.

Indeed, it is unclear if such inefficiencies represent any substantial problem outside of the limited context of instrumental philanthropy. For the vast majority of philanthropists, allocative and productive efficiencies are probably not major considerations. Moreover, "strategic ignorance" about outcomes may even be preferable to being informed (Pritchett 2002). Ignorance guarantees that optimistic conjectures about desired outcomes cannot be falsified. The absence of outcome information may thus be beneficial to maximizing purchaser satisfaction. The virtual impossibility of ever discovering whether a donation produced specific outcomes essentially eliminates the risk of disappointment. In other words, provided that an organization remains trustworthy, donations to a nonprofit automatically and virtually irrevocably license the purchaser's wishful thinking. It may be this license that philanthropists purchase, rather than outcomes per se, although some outcome production for third parties might coincide with license provision.

Thus, in contributing to a nonprofit, a philanthropist purchases a virtually irrevocable "license to feel good." Organizational trustworthiness, coupled with the absence of outcome information, licenses the donor to assume that his or her most desirable outcome scenario has or will materialize. The absence of information ensures that any plausible hypothesis about outcomes is unfalsifiable, and the purchaser may thus feel encouraged to believe that his or her good intentions probably did, or will, result in good outcomes. 
Indeed, experimental research has found widespread evidence of "optimism bias" - defined as an "unwarranted sense of hope about a successful outcome" - in evaluations of prosocial initiatives, regardless of sector and priming effects (Child and Witesman 2019, 2). Moreover, "informed giving" appears to be exceedingly rare (Krasteva and Yildirim 2016, 2013) and purchasers appear to be averse to paying for information that would allow them to make more informed decisions (Null 2011). In general, experimental evidence reveals widespread disinterest in effectiveness information (Vollmer 2017; Karlan and Wood 2017), particularly when easier-to-interpret information is available, such as the overhead ratio (Caviola et al. 2014). ${ }^{14}$ Experiments have also revealed that people will contribute to nonprofits even under the certainty that their contributions will have no impact (Crumpler and Grossman 2008).

The underlying motives of charitable giving have long been a subject of great interest (e. g. Becker 1974; Cornes and Sandler 1984; Olson 1965; Steinberg 1987; Sugden 1984), and the major drivers appear to include awareness, solicitation, low overhead (or the "price" of giving), tax incentives, benefits to one's person or group, impure altruism, reputation (including "conspicuous compassion"), psychological benefits, self-image and selfesteem, personal values, and trusted endorsements (Bekkers and Wiepking 2011). In their extensive literature review of charitable giving drivers, Bekkers and Wiepking $(2011,936)$ note that "[f]rom the behavior of donors we can infer that they do not care so much about the public benefits generated by their contributions." Moreover, "giving is in many cases an almost automatic emotional response, producing a positive mood, alleviating feelings of guilt, reducing aversive arousal, satisfying a desire to show gratitude, or to be a morally just person." Thus, "[p]ositive moods in general may motivate giving" (Bekkers and Wiepking 2011, 938). In short, the available evidence strongly suggests that the expressive, not the instrumental dimension of philanthropy predominates giving motivations.

In this interpretation, nonprofits essentially sell donors licenses to feel good. There is no information asymmetry because the purchaser is also the recipient of the license. The quality of the license is proportional to the trustworthiness of the nonprofit, the optimism of the purchaser, and the amount of the gift. Figure 1 illustrates this "iron circle" in which donors and nonprofits enjoy mutual benefits irrespective of public benefit. Nonprofits exhibit trustworthiness, donors purchase and receive licenses to feel good, and nonprofits receive funding. Purchaser satisfaction is virtually guaranteed because outcome non-observation eliminates the risk of disappointment. Donors pay to feel good, not bad - and that is the point. The iron circle is not only highly efficient for maximizing licensee satisfaction, but is also robust to organizational failure (Seibel 1996). Licensees derive benefits from their purchases regardless of whether organizations succeed or fail to produce public benefits.

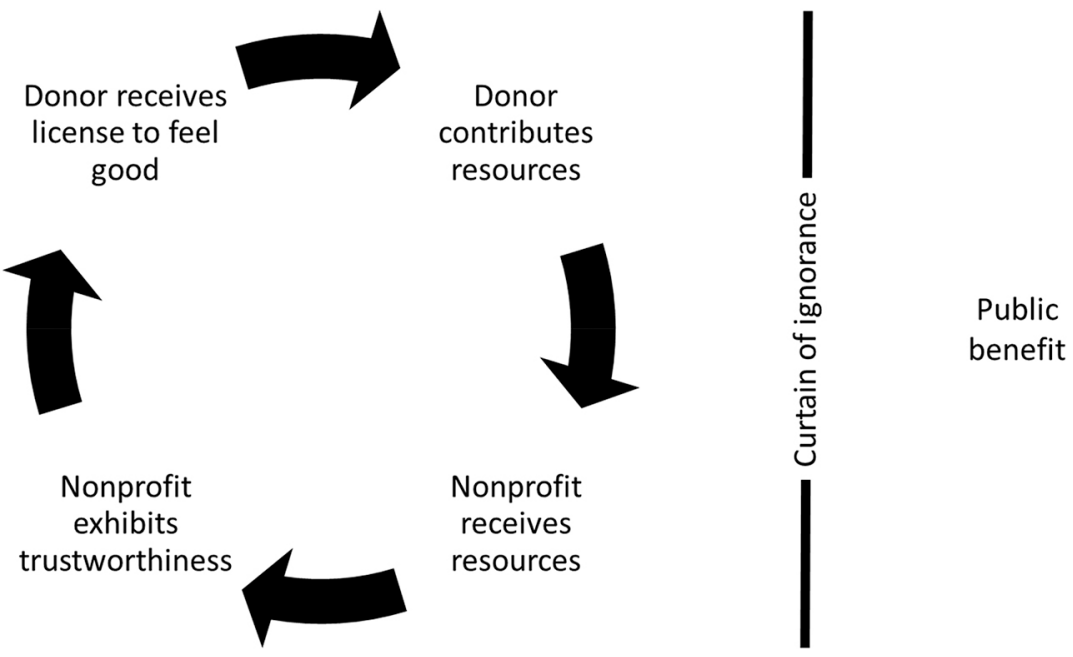

Figure 1: Iron circle of mutual benefit. Enter Figure Credit Details

\subsection{Managerial Implications}

The principal tasks of the nonprofit manager in this scenario are (1) to not observe outcomes or to strategically manage any outcome information and (2) to maintain organizational trustworthiness.

Outcome information is typically produced through program evaluation. Evaluation in the nonprofit sector is a complex topic that has received significant attention. Research has examined evaluation catalysts and obstacles (Mitchell and Berlan 2016), logics (Hall 2014), models (Stufflebeam 2001), constituencies (Campbell and Lambright 2016), feasibility, fit (Gugerty and Karlan 2018b, 2018a), credibility, utilization (Fine, Thayer, and Goghlan 2000), constraints (Bamberger, Rugh, and Church 2003), pitfalls (Hatry and Newcomer 2015), dilemmas (Campbell 2002), and negative consequences, particularly as evaluation relates to accountability and 
learning (Ebrahim 2005). Evaluation controversies have generated a variety of critical perspectives on evaluation (e. g. Bjørnholt and Larsen 2014; Eyben 2013; Mayhew 2012; Perrin 1998; Tassie, Murry, and Bragg 1996) and have invited resistance (Arvidson and Lyon 2013). Empirically, evaluation has been characterized not only as a strategic management tool but also as a resource drain, distraction, and external promotion tool (Carman and Fredericks 2008). In practice, evaluation activity can be merely symbolic or ceremonial (Carman 2011; Gandia 2011; Liket, Rey-Garcia, and Maas 2014), resulting in perfunctory reports and "success stories" rather than credible information. Metaphysical and postmodern or social constructivist critiques have also emerged from the literature (e. g. Dahler-Larsen 2001; Adelman 1996; Herman and Renz 1997, 1999, and 2008) that question the objective reality of outcomes and the fundamental possibility of meaningful measurement. Despite abundant rhetoric about evaluation and high levels of reported evaluation activity over time (Morariu, Athanasiades, and Emery 2012; Morariu et al. 2016; Reed and Moraiu 2010), use of rigorous evaluation methods remains rare (Mitchell and Berlan 2016), especially as nonprofits are often constrained by limited resources and capacities (Carman 2009; Carman and Fredericks 2008; Meehan and Kimberly 2017). Even when evaluation data are produced, donors may prefer to rely on reputation and trust rather than outcome information for decision-making (Carman 2009).

Some of the difficulty in nonprofit evaluation may be due to the possibility that relatively few stakeholders are genuinely interested in credible outcome information and are both willing to pay for it and willing to accept the risk of disappointment. Although it may be unlikely that nonprofit managers are deliberately exploiting information asymmetry or absence, normal and natural tendencies may lead to similar effects. For example, an obvious interest in organizational self-promotion is likely to result in publication bias; resource constraints may prohibit collecting and analyzing outcome data; and limited technical capabilities may result in evaluation designs that are incapable of producing credible information. ${ }^{15}$ Irrespective of any party's deliberate intent, credible outcome information fails to emerge because rigorous evaluation and reporting practices are misaligned with existing incentive structures.

Trustworthiness represents another key managerial imperative for nonprofits. Theory assumes that donors and clients know that an organization is nonprofit, and is therefore trustworthy, so as to overcome contract failure. However, research has reported mixed results about whether organizational form is known to these parties (e. g. Handy et al. 2010; McDougle 2014; Schlesinger, Mitchell, and Gray 2004). Nevertheless, such trust is still likely a key factor in determining donation decisions (Bekkers and Bowman 2009; Konrath and Handy 2018). How do organizations maintain trust? Trustworthiness in the nonprofit sector is signaled, at least in part, through the performance of fiscal propriety. ${ }^{16}$ Garven, Hofmann, and McSwain (2016), for example, describe the evaluation of nonprofits using program spending ratios as proxies for performance. Nonprofits that spend more on overhead are presumed to divert spending away from current programs (Tinkelman 2006), which undermines trustworthiness. Indeed, research largely finds a negative relationship between donations and reported overhead rates (e. g. Gordon, Knock, and Neely 2009; Jacobs and Marudas 2009; Tinkelman and Mankaney 2007). In this understanding, nonprofits signal their trustworthiness by maximizing reported program spending ratios, and donors appear to believe that such organizations provide more and better services and reward these nonprofits with more donations (Mitchell 2018; Mitchell and Calabrese 2019). ${ }^{17}$

Moreover, the program expense ratio is commonly used by information intermediaries, watchdogs, media organizations, government agencies, and institutional funders to evaluate nonprofits, further amplifying its significance (NCN 2013). ${ }^{18}$ Other commonly used ratios include the cost to raise one dollar as well as reserve and debt ratios. Ironically, this pattern of surveillance and discipline based on cost ratios has been associated with the "nonprofit starvation cycle" that appears to harm nonprofit effectiveness (Gregory and Howard 2009; Lecy and Elizabeth 2015; Mitchell 2018; Mitchell and Calabrese 2019; Wing and Hager 2004). Additionally, it has probably contributed to the underreporting of fundraising expenses (Krishnan, Yetman, and Yetman 2006) and other arguably "strategic" behaviors.

The trustworthiness surveillance architecture contains a feedback loop that contributes to the absence of outcome information upon which it is theoretically predicated. Nonprofits are expected to maximize program spending defined as "the mission-related activities of the organization that result in goods or services being distributed to clients, customers, or members" (Flood 2018, 1323). As with information reporting in general, this definition excludes program evaluation, which is - like grant reporting and accounting in general - construed as "not part of the direct conduct or direct supervision of the grant" (FASB 2016, 161). Nonprofits face a tradeoff. Observing outcomes may improve performance, but it may also inflate overhead ratios and reduce perceived trustworthiness. Thus, nonprofits face further disincentives for producing outcome information, as higher overhead rates can deter future contributions. ${ }^{19}$ 


\subsection{Sectoral Implications}

The non-observation of outcomes may improve licensee satisfaction, but it also means that the philanthropic "marketplace" cannot have the information necessary to achieve the allocative efficiency valued by instrumental philanthropists (Mitchell 2014; Ottenhoff and Ulrich 2012). ${ }^{20}$ That is, there must exist superior allocations of resources that would improve aggregate outcome production given a finite amount of philanthropic capital. However, these allocations are undiscoverable because outcomes are neither observed nor priced. Strikingly, the nonprofit marketplace bears a strong resemblance to what North $(1991,103)$ disapprovingly characterized as the economy of a souk with

an enormous number of small transactions, each more or less independent of the next; face to face contacts, and goods and services that are not homogeneous. There are no institutions devoted to assembling and distributing market information; that is, no price quotations, production reports, employment agencies, consumer guides, and so on. Systems of weights and measures are intricate and incompletely standardized $[\ldots]$

In short, such a marketplace is characterized by high information costs, "clientization" in the form of "repeatexchange relationships," and intensive bargaining. Personal connections, trust, voluntary codes of conduct, and self-regulation govern exchanges, and indeed these mechanisms are common in the nonprofit sector (TremblayBoire, Prakash, and Gugerty 2017; Gugerty and Prakash 2010; Prakash and Gugerty 2010; Gugerty 2009; Breen, Dunn, and Sidel 2017).

\section{Problematizing Outcome Unobservability}

If philanthropists are indeed purchasing outcomes, and not licenses, then certain metaphysical and empirical issues concerning outcome unobservability warrant attention. First, the "strong" assumption that nonprofit outcomes are inherently unverifiable represents a challenging metaphysical assertion. In the most extreme case, consider an organization with an efficiency of zero such that a contribution of any dollar amount produces no benefit or outcome for any third party (beyond licensing the purchaser). Such a case would be observationally equivalent to the theorized case in which an organization has positive efficiency but produces unobservable outcomes. In other words, the axiom implies that nonprofit outcomes have no "scientific reality." Arguably, this may be unproblematic for some nonprofit outcomes of a transcendental or spiritual quality, but it may be more difficult to accept for the many philanthropists and nonprofits that understand themselves to be contributing to "real" public benefits. ${ }^{21}$

Second, difficulties also arise in the "weak" version of the assumption in which nonprofit outcomes are observable in principle but not in practice. Specifically, there is no reliable justification as to why observation costs must necessarily exceed the benefits, other than the tautology that nonprofit outcomes must by definition be of the unobservable type or else contracts would not fail and nonprofits would not exist. The mere existence of nonprofits does not itself demonstrate that outcome measurement is inherently unworthwhile; it could equally imply that purchasers prefer to remain ignorant and therefore favor intermediaries with a comparative advantage in trustworthiness.

Outcome unobservability precludes the possibility of identifying and pricing outcomes and is therefore inconsistent with instrumental philanthropy. Indeed, instrumental philanthropy can only be viable for those cases in which outcomes are observable and contract failure does not occur. Moreover, in such cases, nonprofits have no inherent comparative advantage. In Hansmann's $(1981,523)$ words:

When contract failure is not involved, there is generally no reason to expect nonprofit firms to provide any particular advantage over profit-seeking firms. On the contrary, in such a situation, one would expect nonprofits to be less desirable suppliers than propriety firms, given their problems of limited access to capital and poor incentives for efficient production.

The nonprofit is an ideal institutional form for expressive philanthropy and the production of unobservable outcomes, or alternatively (if not equivalently), licensure. However, the irrevocable licensure feature that makes the nonprofit form suitable for the expressive function makes it unsuitable for the instrumental function. This is not to say that nonprofits cannot or should not play an important role in instrumental philanthropy - far from it. Rather, the conclusion underscores the central importance of information for instrumental philanthropy. Outcomes must be "real" and must be observed. Therefore, assuming that information is costly, information costs must be incurred. 


\section{Information Costs}

Theoretically, instrumental philanthropists seek to maximize outcomes per dollar and thus require information about outcomes and their unit costs. If instrumental philanthropy is to be viable, a principal challenge is therefore the mitigation and defrayal of information costs. These costs can be understood and categorized according to their incidence: supply-side costs are mostly incurred by nonprofits or other outcome producers, while demand-side costs are mostly incurred by donors, philanthropists, or the purchasers of outcomes generally.

Participants in an allocatively efficient outcomes marketplace must mitigate or defray at least four categories of supply-side information costs: (1) distortion costs, (2) evaluation costs, (3) disclosure costs, and (4) auditing costs. These are summarized in Table 1.

Table 1: Information costs.

\begin{tabular}{|c|c|c|}
\hline & Information cost & Description \\
\hline \multirow[t]{4}{*}{ Supply-side } & Distortion & $\begin{array}{l}\text { Poor measurement perverts behavior, wasting resources and harming } \\
\text { outcomes }\end{array}$ \\
\hline & Evaluation & The direct and indirect resource costs of program evaluation \\
\hline & Disclosure & $\begin{array}{l}\text { The costs of publicly reporting information about outcomes in a } \\
\text { standardized format }\end{array}$ \\
\hline & Auditing & The costs of credibly assuring the accuracy of reported outcome information \\
\hline \multirow[t]{3}{*}{ Demand-side } & Search and discovery & $\begin{array}{l}\text { The costs of identifying relevant organizations and ascertaining their } \\
\text { outcomes and unit costs }\end{array}$ \\
\hline & $\begin{array}{l}\text { Bargaining and } \\
\text { decision making }\end{array}$ & $\begin{array}{l}\text { The costs of information intermediation and comparative analysis to inform } \\
\text { allocation decisions }\end{array}$ \\
\hline & $\begin{array}{l}\text { Surveillance and } \\
\text { enforcement }\end{array}$ & $\begin{array}{l}\text { The costs of ensuring accurate disclosure, policing cheating and fraud, and } \\
\text { establishing and maintaining reporting standards }\end{array}$ \\
\hline
\end{tabular}

Distortion costs emerge when performance incentive structures reward counterproductive behavior. For example, if teacher compensation is tied to students' test scores, teachers may encourage cheating at the expense of learning. Performance measurement systems must therefore be carefully designed to create incentive systems sufficiently aligned with the desired objectives.

Evaluation costs refer to the financial costs incurred in outcome evaluation. These include the costs of designing and implementing evaluations as well as maintaining the necessary administrative infrastructure and technical capacities for data collection, program evaluation, and outcome accounting systems.

Disclosure costs include the costs of publishing outcome information in a comprehensible and useful format. Although many nonprofits already produce annual reports describing outcomes, these are unstandardized and unassured. Information users need to be able to easily obtain, interpret, and compare credible outcome data. This requires generally accepted accounting principles for outcomes and standardized outcome disclosure instruments.

Auditing costs are incurred to assure the credibility of self-reported outcome information. ${ }^{22}$ Currently, outcomes are not part of the formal accounting regime in the United States and the sector lacks an outcome auditing infrastructure appropriate for its needs and commensurate with its scale. However, generally agreedupon accounting standards could be developed for nonprofit outcome disclosures analogously to existing financial accounting standards. Making outcome disclosures auditable would improve information credibility and introduce a level of standardization currently absent in the US context.

The transaction cost literature identifies at least three relevant types of mostly demand-side costs (Coase 1937; North 1987; Allen 1998). These include the costs of (1) search and discovery, (2) bargaining and decision making, and (3) surveillance and enforcement.

Search and discovery costs include a purchaser's costs to identify relevant nonprofits and to obtain information about their outcomes and corresponding unit costs. Although a variety of intermediaries currently provide databases of nonprofits, none provides credible outcome information at scale. ${ }^{23}$

Bargaining and decision-making costs include the costs of selecting or negotiating contracts, comparing options or proposals, and analyzing data to determine efficient resource allocations. Both search and discovery and bargaining and decision making costs would likely require an industry of specialized intermediaries (Benjamin 2010; Ruff 2013; Ruff and Olsen 2016) to compile and evaluate information to support comparative analysis and to provide relevant information to inform giving. Finally, surveillance and enforcement activities are necessary to motivate accurate disclosure, discourage cheating and fraud, and establish and maintain reporting standards. ${ }^{24}$ 
Instrumental philanthropy requires "high-quality information [that] will lead donors to allocate funds more strategically to organizations doing the best work" (O'Flanagan, Harold, and Brest 2008, I). An efficient marketplace would require a broader "philanthropy ecosystem" capable of generating, managing, reporting, and evaluating information to facilitate outcome-maximizing transactions (Schmidt 2014). Although pieces of this infrastructure have started to emerge in recent years, the overall information ecosystem remains immature.

Contract failure theory is predicated on the axiom that extreme information costs make nonprofit outcomes unobservable even in cases where such outcomes might be observable in principle. However, in the decades since the theory was developed, a variety of technological innovations have radically reduced many information costs and fundamentally transformed the informational environment. The advent of the internet; search engines; digital filing; fast, efficient, and inexpensive data processing and storage capabilities; and the emergence of online information intermediaries and data transparency platforms all offer important opportunities to support instrumental philanthropy with reduced information costs. Additionally, public policy could be leveraged to help serve the informational needs of instrumental philanthropy.

\section{Policy Considerations}

Longstanding "policy neglect" of the nonprofit sector has led to calls for reforms to update regulatory structures to accommodate developments such as sectoral blurring, increased demands for transparency, and improved accountability (Anheier and Toepler 2019). The contemporary nonprofit accountability model emphasizing upward financial reporting to donors and regulators is simply not meeting the needs and expectations of newer generations of stakeholders, especially those more focused on results and impact. Increasingly, these stakeholders are demanding more information about additional dimensions of nonprofit performance and accountability, including information about program goals and outcomes. However, the presence of information costs present challenges. Below, we identify a number of public policy considerations for supporting the instrumental function of philanthropy.

\subsection{Create a Nonprofit Accounting Standards Board}

The problem of information costs is fundamentally an accounting problem - the problem of "accounting for outcomes" (Mitchell 2017, 2013). As the Financial Accounting Standards Board (FASB), which issues guidance on nonprofit accounting and financial reporting in the US, noted:

Information about an organization's service efforts and accomplishments is useful to resource providers and others in assessing the performance of a nonbusiness organization...The accomplishments of nonbusiness organizations generally cannot be measured in terms of sales, profit, or return on investment (FASB 1980, 16).

However, since the FASB began discussions about service efforts and accomplishments in the 1970s, little, if any, progress has occurred. Due to this impasse, a legitimate question is whether the FASB is the appropriate accounting standard-setter for nonprofits in the United States. While traditional financial indicators are important for determining the financial viability of nonprofits, they do not represent the primary mission-based purpose for which most nonprofits explicitly exist, nor should they be the principal basis for informing donor decisionmaking, especially for instrumental philanthropists. Further, the current accounting framework focused on donor-restricted contributions adds little to understanding organizational outputs and outcomes. Hence, for instrumental philanthropists accounting standards such as those in the United States that do not focus on the outcomes that nonprofits produce cannot truly inform "rational decisions about the allocation of resources to those organizations" (FASB 1980). As such, it is surprising that the nonprofit sector - unlike the public sector, which has the Governmental Accounting Standards Board - lacks its own standard-setter to issue best practices for nonprofit outcome accounting. ${ }^{25}$ As posed decades ago, "Are not-for-profit organizations truly so different from for-profit entities that we need additional elements and quite a different financial reporting system? They are indeed" (Mautz 1989).

\subsection{Designate Program Evaluation as a Program Expense}

One relatively simple means of incentivizing outcome observation could be to alter the current accounting treatment of evaluation costs. The accounting definition of program spending could be expanded to include 
the monitoring and evaluation of "goods or services being distributed" (Flood 2018, 1323), although this might require a paradigmatic shift toward a financial accounting model more supportive of an instrumental view of the nonprofit sector. At a minimum, designating program evaluation as a program expense would reduce the disincentives nonprofits currently face against generating information about program outcomes.

\subsection{Introduce an Outcome Reporting Regime}

Another accounting reform could be to ask nonprofits to allocate their total expenses across their program goals and accomplishments analogously to how nonprofits are currently required to allocate their total expenses across functional expense categories (i. e. programs, management and general, and fundraising) ${ }^{26}$ In addition to providing more detailed information about what nonprofits are attempting to accomplish, this could effectually price program accomplishments. Nonprofits could choose to account for activities, outputs, outcomes, or impacts, depending on their capabilities. Nonprofits with the interest and capacity could select from a menu of acceptable outcome accounting methods, such as CEA or SROI, for example.

The principal information disclosure mechanism for public charities in the United States, the IRS Form 990, does contain a Statement of Program Service Accomplishments (Part III). However, the IRS provides little meaningful oversight over the accuracy of reported information (Keating and Frumkin 2003), and because program service information is not part of a financial reporting regime, any reported outcome information is, by definition, not audited. Including outcome reporting as part of the existing financial reporting regime could significantly improve the quality of information already reported to the IRS. For such reporting to be meaningful and credible it would need to be informed by agreed-upon accounting standards and be auditable by bodies with appropriate competence to review outcome information.

McConville and Cordery (2018) identify the US accounting regime as relying upon market regulation with no performance measurement guidance. In contrast, they identify "new governance" regimes in the UK and New Zealand in which the nonprofit sector is consulted to ensure that accounting and performance standards meet the needs of various stakeholders. In these countries (and Australia is currently developing performance reporting standards), performance data are an accepted factor in reporting. The United States could adopt a system in which nonprofits adhere to a particular accounting and regulatory structure by default, but those who desire particular tax advantages self-select into a different regime in which performance measures are included alongside financial disclosures. This would situate these nonprofits in between the "new governance" and the "market regulation201D; models of McConville and Cordery (2018), and would allow nonprofits the freedom to opt-in to a more robust reporting model. Moving toward this regulatory and accounting regime would move public policy toward the outcome reporting needed for instrumental philanthropy to succeed.

\subsection{Tax Policy Reform}

The current US legal framework confers tax benefits to organizations on the basis of their nonprofit status, not necessarily according to whether they generate public benefits. This means that, for example, nonprofits that do not produce public benefits may still be tax-exempt and receive tax-deductible contributions, while for-profits that do produce public benefits are excluded. Legal scholars have questioned the rationality behind this taxation principle (Malani and Posner 2007). In a broader critique, Fricke (2015) analyzed all the major justifications for the nonprofit income tax exemption and found them to be unconvincing. ${ }^{27}$ Nevertheless, the production of public benefits seems to be a leading candidate as a principle for the allocation of public subsidies.

Tax credits are a possible tool for subsidizing instrumental philanthropy and the production of public benefits. Nonprofits that opt-in to an enhanced information reporting model could be made automatically eligible to receive contributions offset by such tax credits. More favorable than tax-deductibility, tax credits allow donors who contribute to eligible nonprofits to directly reduce their tax liability by up to the amount of the contribution. A version of this policy already exists in France. ${ }^{28}$ Such a tax policy would also have the benefit of incentivizing philanthropy among a larger number of lower-income taxpayers. Following the "Tax Cuts and Jobs Act of 2017," individual charitable giving dropped in 2018 by USD $\$ 15.5$ billion as fewer taxpayers were able to claim the charitable deduction by itemizing. ${ }^{29}$ According to the Tax Policy Center, the average effective subsidy for charitable giving in the United States dropped from $8.1 \%$ to $3.3 \%$ for moderate-income taxpayers and from $30.4 \%$ to $28.9 \%$ for the top one percent. ${ }^{30}$ The subsidy has not only declined but also now excludes more lower-income taxpayers. Tax credits, by contrast, could offer a more attractive and more egalitarian option that could be targeted to subsidize nonprofits that meet enhanced information disclosure requirements, or more restrictively, that demonstrably contribute to defined public benefits. 


\subsection{Market Solutions}

It is conceivable that the proponents of instrumental philanthropy could build out the requisite infrastructure for their project themselves. The difficulty is that instrumental philanthropy requires a significantly more sophisticated philanthropic ecosystem than currently exists (Schmidt 2014), with numerous intermediaries serving financial, evaluative, technical, fiduciary (Gugelev et al. 2019), capacity-building, surveillance, allocation, risk management, and communicative functions (Benjamin 2010). Instrumental philanthropists have identified the missing pieces of the infrastructure (e. g. Henderson 2014; O'Flanagan, Harold, and Brest 2008) and some have begun to take action. For example, the Effective Altruism Meta Fund pools donations to improve talent, information, and capital for instrumental philanthropy. ${ }^{31}$ However, the daunting scale of such a project coupled with the need for detailed technical coordination suggests that public policy may be a more promising approach.

\section{Conclusion}

Contract failure theory entertains the fundamental question of why nonprofits exist at all, given that for-profits could presumably accomplish what nonprofits seek to accomplish without the need for another institutional form. According to this theory, nonprofits exist because they are more trustworthy than for-profits in the production of unobservable outcomes. However, the notion of outcome unobservability is inimical to the project of instrumental philanthropy. If the reason for outcome unobservability is high information costs, then policymakers and other interested stakeholders can seek to mitigate and defray those costs. If, however, nonprofit outcomes are unobservable because they are not real, because the benefits are truly not worthwhile, or because public policy caters to licensees who prefer ignorance, then instrumental philanthropy is unlikely to ever succeed at any significant scale in the United States.

At face value, most stakeholders would probably agree that nonprofits exist, at least in part, to produce some manner of public benefits, and that this public purpose justifies at least some of the tax advantages that nonprofits enjoy. In 2015, tax deductions and exemptions cost federal and state governments more than $\$ 137.3$ billion in forgone tax revenues (Pratt 2019). ${ }^{32}$ In 2018, the charitable deduction alone cost $\$ 58.1$ billion, with $84 \%$ of the benefits to individuals accruing to households earning over $\$ 200,000$ (Crandall-Hollick and Sherlock 2018). The current informational environment does not permit accurate estimates of the substantive public benefits associated with current nonprofit tax policy, nor those associated with charitable giving in general. It also precludes accurate estimates of what could be gained by the improved allocative efficiency that instrumental philanthropy promises. Perhaps if the benefits of increased impact per dollar enabled by superior information were better understood, then there would be greater interest in instrumental philanthropy and a higher tolerance for incurring information costs.

\section{Notes}

1 For example, see: https://pfs.urban.org/ and https://www.payforsuccess.org/.

2 Mission valence refers to the perceived attractiveness of a mission. See: (Rainey and Steinbauer 1999; Wright and Pandey 2011).

3 Research estimated that "high-impact" givers represented about $16 \%$ of donors in 2010 and about 17\% by 2015 (Neighbor et al. 2015, 126).

4 See, for example, the special issue of Essays in Philosophy concerning effective altruism: (MacAskill 2017).

5 Giving USA estimated USD $\$ 427.71$ billion in total US charitable giving in 2018 from individuals, bequests, foundations, and corporations. Individual giving in 2018 was USD \$292.09 billion and in 2015 was USD \$264.58 billion (Giving USA 2016, 2019). Based on research from the Camber Collective placing "high-impact" donors at about $17 \%$ of donors (Neighbor et al. 2015), the magnitude of individual giving potentially aligned with instrumental philanthropy can be estimated at about USD \$44.98 billion in 2015.

6 The US Internal Revenue Service (IRS), which administers the IRC, has issued additional guidance, stating that: "The term charitable is used in its generally accepted legal sense and includes relief of the poor, the distressed, or the underprivileged; advancement of religion; advancement of education or science; erecting or maintaining public buildings, monuments, or works; lessening the burdens of government; lessening neighborhood tensions; eliminating prejudice and discrimination; defending human and civil rights secured by law; and combating community deterioration and juvenile delinquency" (IRS 2018).

7 Steinberg and Gray (1993) also call attention to informational problems attendant to third-party payment.

8 The constraint prohibits private inurement and private benefit as described in the IRC, specifically: "no part of the net earnings [of a nonprofit may inure] to the benefit of any private shareholder or individual" (Internal Revenue Act n.d.).

9 This formulation represents an extraordinarily strong statement about the nonprofit production function: non-opportunistic spending necessarily improves nonprofit outcomes.

10 This preference has gained legal standing. Individuals only receive tax deductibility for donations made to 501(c)(3)s, and private foundations can only count grants made to such nonprofits toward their required payout requirement. 
11 According to Krashinsky (1997): "If consumers could accurately judge what was being produced and could shop around among competing firms, the problem of opportunistic behavior would disappear; but in that case, the justification for non-profit organisations would also fall by the wayside."

12 In other words, neither purchasers nor nonprofits have information about outcomes. According to Ortmann and Schlesinger (1997, 101), "Hansmann"s rationale treated the external and internal agency problems asymmetrically when their structure [...] is the same."

13 See: (Hansmann 1981, 521; Moore 2000). The nondistribution constraint also ensures that nonprofit managers lack profit incentives to minimize costs. Thus, "inefficiency is inherently embedded in nonprofit services" (Kim and Kim 2016, 2942).

14 The research suggests that people exhibit "evaluability bias" by weighting the importance of information proportionately to its ease of interpretation. For example, when presented with information about both overhead costs and cost-effectiveness, people favor the organization with low overhead (Caviola et al. 2014).

15 Indeed, research has suggested that more rigorous evaluation designs are more likely to be used when they are most likely to reveal success (Mitchell and Berlan 2016).

16 For example, one survey found that "eighty percent of survey respondents said that the best way to determine trustworthiness of a charity is to look at its financial performance." See: (Gano 2019; Sauer 2016).

17 Such indicators are often regarded as "efficiency" measures, although they do not technically measure efficiency as they take no account of outputs or outcomes. See: (Coupet and Haynie 2019).

18 For example, see: Charity Navigator (https://www.charitynavigator.org/), the Better Business Bureau Wise Giving Alliance (https://www.give.org/), Christian Science Monitor (https://www.csmonitor.com/), Forbes Magazine (https://www.forbes.com/), and CharityWatch (https://www.charitywatch.org/), among others. Although the overhead ratio is conceptually similar to the indirect cost rate, the two can diverge. Both are used. See: (NCN 2013).

19 For a brief review of the substantiating literature, see: (Mitchell and Calabrese 2019).

20 The report from GuideStar (subsequently Candid; a prominent nonprofit information intermediary in the US), noted: “It doesn't take much experience in the nonprofit sector to know that charitable giving doesn't share many of the characteristics of efficient markets" (Ottenhoff and Ulrich 2012, 5).

21 This discussion obviously sets aside what could be a much more elaborate discussion of epistemology. For clarity, "observable" should be read very expansively. For example, subjective psychological states are sometimes regarded as unobservable. However, these are readily "observable" by means of inference and the evaluation of observable implications. For example, some might regard "happiness" as an unobservable outcome. However, a happy person might be observed smiling or might answer "yes" when asked if they are happy. Thus, observations can be made to decide the question. Truly unobservable outcomes, by contrast, are undecidable by any means. For example, it is impossible to determine whether an animal sacrifice pleases the gods.

22 Although nonprofits might arguably be relied upon to report outcome information honestly, because they are trustworthy, the nondistribution constraint would not necessarily guarantee the accuracy of self-reported information or its conformity to acceptable standards. 23 However, ImpactMatters appears to be attempting something along these lines. See: https:/ /www.impactmatters.org/.

24 North $(1987,425)$ provides an instructive argument about the general necessity of incurring such costs. In "high income societies ... impersonal exchange involves the high measurement costs of complex contracting necessary to realize the potential of the technology that comes from specialization. Neither self-enforcement by the parties themselves nor trust is a viable way of enforcing such contracts." Indeed, the US long ago established legal and cultural architectures to defray the information costs necessary for facilitating private capital accumulation, but a similar effort has not yet been devoted to optimizing the production of social outcomes (Ruff and Olsen 2016; Ruff 2013).

25 The GASB attempted to implement service efforts and accomplishments (SEA) into accounting standards. Many governments and their organizations argued this was outside the purview of accounting standards and threatened to remove their support of GASB. This resulted in GASB indefinitely shelving the project. See: (Behn 2007).

26 Distortion effects and other costs could be further mitigated by allowing nonprofits to select their own measures and methods and to disclose their outcome information to multiple stakeholders in a standardized format (Mitchell 2014, 2013, and 2017).

27 Much of the difficulty in discussing nonprofit tax policy reform lies in the unnecessary conflation of "nonprofit" "charitable" or public benefit-serving, and "tax-exempt" in both law an in common parlance that Hansmann (1981) scrupulously sought to avoid.

28 See: https://www.cof.org/country-notes/nonprofit-law-france.

29 See: https://www.aei.org/society-and-culture/2018-charitable-giving-dips-as-predicted/.

30 See: https://www.taxpolicycenter.org/briefing-book/how-did-tcja-affect-incentives-charitable-giving.

31 See: https://app.effectivealtruism.org/funds/ea-community.

32 This estimate does not include property tax exemptions, which are difficult to estimate on a national scale.

\section{References}

Acumen Fund Metrics Team. 2007. Acumen Fund Concepts: The Best Available Charitable Option. In Acumen Fund, 1-5. New York, NY: Acumen Fund. https://acumen.org/wp-content/uploads/2013/03/BACO-Concept-Paper-final.pdf.

Adelman, Clem. 1996. “Anything Coes: Evaluation and Relativism." Evaluation 2 (3): 291-305.

Allen, Douglas W. 1998. Transaction Costs. In Encyclopedia of Law \& Economics, edited by Boudewijn Bouckaert, and Cheltenham, United Kingdom: Edward Elgar.

Anheier, Helmut K., and Stefan Toepler. 2019. "Policy Neglect: the True Challenge to the Nonprofit Sector." Nonprofit Policy Forum. https://doi.org/10.1515/npf-2019-0041.

Arnsberger, Paul, Melissa Ludlum, Margaret Riley, and Mark Stanton. 2008. "A History of the Tax-Exempt Sector: An SOI Perspective." Statistics of Income Bulletin (Winter): 105-35. https://www.irs.gov/pub/irs-soi/tehistory.pdf.

Arvidson, Malin, and Fergus Lyon. 2013. "Social Impact Measurement and Non-profit Organisations: Compliance, Resistance, and Promotion." Voluntas. https://doi.org/10.1007/s11266-013-9373-6.

Bamberger, Michael, Jim Rugh, and Mary Church. 2003. "Shoestring Evaluation: Designing Impact Evaluations under Budget, Time and Data Constraints." American Journal of Evaluation 25 (1): 5-37.

Bartlett, Valerie, Antony Bugg-Levine, David Erickson, lan Galloway, Janet Genser, and Jennifer Talansky, eds. 2017. What Matters: Investing in Results to Build Strong, Vibrant Communities. New York: Federal Reserve Bank of San Francisco and Nonprofit Finance Fund. 
Becker, G. S. 1974. “A Theory of Social Interactions." Journal of Political Economy 82 (6): 1063-93.

Behn, Robert D. 2007. "Beyond the GASB-CFOA Brawl." Governing The States and Localities. Accessed August 20. https://www.governing.com/columns/mgmt-insights/Beyond-the-GASB-CFOA-Brawl.html.

Bekkers, Rene, and Woods Bowman. 2009. "The Relationship between Confidence in Charitable Organizations and Volunteering Revisited." Nonprofit and Voluntary Sector Quarterly 40 (5): 924-73.

Bekkers, René, and Pamala Wiepking. 2011. “A Literature Review of Empirical Studies of Philanthropy: Eight Mechanisms that Drive Charitable Civing." Nonprofit and Voluntary Sector Quarterly 40 (5): 924-73.

Benjamin, Lehn M. 2010. "Mediating Accountability: How Nonprofit Funding Intermediaries Use Performance Measurement and Why It Matters for Covernance." Public Performance and Management Review 33 (4): 594-618.

Bjørnholt, Bente, and Flemming Larsen. 2014. "The Politics of Performance Measurement: "Evaluation Use as Mediator for Politics". . Evaluation 20 (4): 400-11.

BOND, and ITAD. 2012. Value for Money: What It Means for UK NCOs. London: BOND.

Breen, Oonagh B., Alison Dunn, and Mark Sidel, eds. 2017. Regulatory Waves: Comparative Perspectives on State Regulation and Self-Regulation Policies in the Nonprofit Sector. New York: Cambridge University Press.

Brest, Paul. 2012. “A Decade of Outcome-Oriented Philanthropy." Stanford Social Innovation Review. http://www.ssireview.org/articles/entry/a_decade_of_outcome_oriented_philanthropy.

Brest, Paul. 2015. “Strategic Philanthropy and Its Discontents." Stanford Social Innovation Review. https://ssir.org/up_for_debate/article/strategic_philanthropy_and_its_discontents.

Campbell, David. 2002. “Outcomes Assessment and the Paradox of Nonprofit Accountability." Nonprofit Management \& Leadership 12 (3): 243-59.

Campbell, David A., and Kristina T. Lambright. 2016. "Program Performance and Multiple Constituency Theory.” Nonprofit and Voluntary Sector Quarterly 45 (1): 150-71.

Carman, Joanne C. 2009. “Nonprofits, Funders, and Evaluation: Accountability in Action." The American Review of Public Administration 39 (4): 374-90.

Carman, Joanne G., and Kimberly A. Fredericks. 2008. “Nonprofits and Evaluation: Empirical Evidence From the Field." New Directions for Evaluation 119: 51-71.

Carman, Joanne G. 2011. “Understanding Evaluation in Nonprofit Organizations.” Public Performance and Management Review 34 (3): $350-77$.

Caviola, Lucius, Jim. A. Nadira Faulmüller, C. Everett, Julian Savulescu, and Cuy Kahane. 2014. “The Evaluability Bias in Charitable Civing: Saving Administrationcosts or Saving Lives?" Judgement and Decision Making 9 (4): 303-15.

Child, Curtis, and Eva M. Witesman. 2019. “Optimism and Bias When Evaluating a Prosocial Initiative.” Social Science Quarterly. https://doi.org/10.1111/ssqu.12585.

Clist, Paul. 2018. “Payment by Results in International Development: Evidence from the First Decade." Development Policy Review. https://doi.org/10.1111/dpr.12405.

Coase, Ronald H. 1937. “The Nature of the Firm." Economica 4 (16): 386-405.

Cornes, R., and T. Sandler. 1984. “Easy Riders, Joint Production, and Public Coods." The Economic Journal 94 (375): 580-98.

Coupet, Jason, and Jessica L. Haynie. 2019. "Toward a Valid Approach to Nonprofit Efficiency Measurement." Nonprofit Management $\&$ Leadership 29 (2): 299-320. https://doi.org/10.1002/nml.21336.

Crandall-Hollick, Margot L., and Molly F. Sherlock. November 13, 2018. The Charitable Deduction for Individuals. Congressional Research Service (Washington, DC).

Crumpler, Heidi, and Philip J. Grossman. 2008. “An Experimental Test of Warm Clow Civing." Journal of Public Economics 92: 1011-21.

Dahler-Larsen, Peter. 2001. "From Programme Theory to Constructivism: On Tragic, Magic and Competing Programmes." Evaluation 7 (3): $331-49$.

Ebrahim, Alnoor. 2005. “Accountability Myopia: Losing Sight of Organizational Learning." Nonprofit and Voluntary Sector Quarterly 34 (1): $56-$ 87.

Emerson, Jed, Jay Wachowicz, and Suzi Chun. 2000. Social Return on Investment: Exploring Aspects of Value Creation in the Nonprofit Sector. The Roberts Foundation. CA: Roberts Enterprise Development Fund. https://redf.org/app/uploads/2013/10/REDF-Box-Set-Vol.-2-SROI-Paper2000.pdf.

Eyben, Rosalind. 2013. Uncovering the Politics of "Evidence" and "Results". A Framing Paper for Development Practitioners. The Big Push Forward. http://bigpushforward.net/wp-content/uploads/2011/01/The-politics-of-evidence-11-April-20133.pdf.

FASB. 1980. Statement of Financial Accounting Concepts No. 4: Objectives of Financial Reporting by Nonbusiness Organizations. Financial Accounting Standards Board (Norwalk, CT).

FASB. 2016. FASB Accounting Standards Update No. 2016-14 Not-for-Profit Entities (Topic 958). Norwalk, CT: Financial Accounting Standards Board.

Fine, Allison H., Colette E. Thayer, and Anne T. Goghlan. 2000. “Program Evaluation Practice in the Nonprofit Sector." Nonprofit Management \&Leadership 10 (3): 331-39.

Flood, Joanne M. 2018. Interpretation and Application of Cenerally Accepted Accounting Principles. Hoboken, N]: John Wiley \& Sons, Inc.

Fricke, Michael. 2015. “The Case against Income Tax Exemption for Nonprofits." St John's Law Review 89 (4): 1129-84.

Frumkin, Peter. 2002. On Being Nonprofit: A Conceptual and Policy Primer. Cambridge, MA: Harvard University Press.

Gandia, Juan L. 2011. "Internet Disclosure by Nonprofit Organizations: Empirical Evidence of Nongovernmental Organizations for Development in Spain." Nonprofit and Voluntary Sector Quarterly 40 (1): 57-78.

Gano, Karen. 2019. "Regulators and Nonprofits - Working Together to Protect the Public Trust." National Council of Nonprofits. Last Modified January 23. Accessed August 1. https://www.councilofnonprofits.org/thought-leadership/regulators-and-nonprofits-workingtogether-protect-the-public-trust. 
Garven, Sarah A., Mary Ann Hofmann, and Dwayne N. McSwain. 2016. “Playing the Numbers Came: Program Ratio Management in Nonprofit Organizations." Nonprofit Management \& Leadership: 1-16. https://doi.org/10.1002/nml.21201.

GiveWell. 2017. “Cost-Effectiveness." GiveWell. Accessed July 29. https://www.givewell.org/how-we-work/our-criteria/cost-effectiveness.

Giving USA. 2016. Giving USA 2016: The Annual Report on Philanthropy for the Year 2015. Chicago, IL: Giving USA.

Giving USA. 2019. Giving USA 2019: the Annual Report on Philanthropy for the Year 2018. Chicago, IL: Civing USA.

Coldseker, Sharna, and Michael Moody. 2017. Generation Impact: How Next Ceneration Donors are Revolutionizing Giving. Hoboken, N]: John Wiley \& Sons.

Cordon, C. Wayne, and Nicholas Babchuk. 1959. “A Typology of Voluntary Associations.” American Sociological Review 24 (1): $22-29$.

Cordon, Teresa P., Cathryn L. Knock, and Daniel G. Neely. 2009. “The Role of Rating Agencies in the Market for Charitable Contributions: an Empirical Test." Journal of Accounting and Public Policy 28: 469-84.

Gregory, Ann Goggins, and Don Howard. 2009. “The Nonprofit Starvation Cycle." In Stanford Social Innovation Review, 49-53. Stanford, CA: Stanford Center on Philanthropy and Civil Society at Stanford University.

Gugelev, Alice, Avnish Cungadurdoss, Jared Lee, Richard Sedlmayr, and Andrea E. Stumpf. 2019. Conceptualizing Fiduciary Structures that Create Demand for Development Outcomes. Washington, DC: Center for Clobal Development. DOI: 10.31235/osf.io/7cdsn.

Gugerty, Mary Kay. 2009. “Signaling Virtue: Voluntary Accountability Programs Among Nonprofit Organizations." Policy Sciences 42 (3): $243-$ 73.

Gugerty, Mary Kay, and Dean Karlan. 2018a. The Coldilocks Challenge: Right-Fit Evidence for the Social Sector. New York: Oxford University Press.

Gugerty, Mary Kay, and Dean Karlan. 2018b. “Ten Reasons Not to Measure Impact-and What to Do Instead." Stanford Social Innovation Review (Summer) 16 (3): 41-47.

Gugerty, Mary Kay, and Aseem Prakash, eds. 2010. Voluntary Regulation of NCOs and Nonprofits: An Accountability Club Framework. New York: Cambridge University Press.

Custafsson-Wright, Emily, and Izzy Boggild-Jones. 2018. “Are Impact Bonds and Outcome Funds a Solution to the Clobal Learning Crisis?” Education Plus Development (blog), Brookings. June 18. https://www.brookings.edu/blog/education-plus-development/2018/06/18/areimpact-bonds-and-outcome-funds-a-solution-to-the-global-learning-crisis/.

Hall, Matthew. 2014. "Evaluation Logics in the Third Sector." Voluntas 25: 307-36.

Hall, Peter Dobkin. 2010. "Historical Perspectives on Nonprofit Organizations in the United States." In The Jossey-Bass Handbook of Nonprofit Leadership and Management, edited by David O. Renz, 3-41. San Francisco, CA: Jossey-Bass.

Handy, F., S. Seto, A. Wakaruk, B. Mersey, A. Mejia, and L. Copeland. 2010. “The Discerning Consumer: Is Nonprofit Status a Factor?” Nonprofit and Voluntary Sector Quarterly 39 (5): 866-83.

Hansmann, Henry. 1981. “Reforming Nonprofit Corporation Law.” University of Pennsylvania Law Review 129 (3): 497-623.

Hansmann, Henry. 1996. "The Changing Roles of Public, Private, and Nonprofit Enterprise in Education, Health Care, and Other Human Services." In Individuals and Social Responsibility: Child Care, Education, Medical Care, and Long-term Care in America, edited by V. Fuchs, 245-75. Chicago, IL: University of Chicago Press.

Hansmann, Henry. B. 1980. "The Role of Nonprofit Enterprise." The Yale Law Journal 89 (5): 835-902.

Hatry, Harry P., and Kathryn E. Newcomer. 2015. "Pitfalls in Evaluations." In Handbook of Practical Program Evaluation, edited by Kathryn E. Newcomer, Harry P. Hatry, and Joseph S. Wholey, 701-24. Hoboken, N]: Jossey-Bass.

Henderson, Eric ]., ed. 2014. Selected Readings: Making Sense of Data and Information in the Social Sector. Stanford, CA: Markets for Cood, Bill \& Melinda Gates Foundation.

Herman, Robert D., and David O. Renz. 1997. “Multiple Constituencies and the Social Construction of Nonprofit Organization Effectiveness." Nonprofit and Voluntary Sector Quarterly 26 (2): 185-206.

Herman, Robert D., and David O. Renz. 1999. “Theses on Nonprofit Organizational Effectiveness." Nonprofit and Voluntary Sector Quarterly 28 (2): $107-26$.

Herman, Robert D., and David O. Renz. 2008. "Advancing Nonprofit Organizational Effectiveness Research and Theory: Nine Theses." Nonprofit Management \& Leadership 18 (4): 399-415.

Internal Revenue Act n.d. 26 U.S. Code $\$ 501$ (c)(3). https://www.law.cornell.edu/uscode/text/26/501.

IRS. 2018. “Exempt Purposes - Internal Revenue Code Section 501(c)(3)." United States Internal Revenue Service. Last Modified June $22,2018$. Accessed October 24. https://www.irs.gov/charities-non-profits/charitable-organizations/exempt-purposes-internal-revenue-codesection-501c3.

Jacobs, Fred A., and Nicholas P. Marudas. 2009. “The Combined Effect of Donation Price and Administrative Inefficiency on Donations to US Nonprofit Organizations." Financial Accountability \& Management 25: 33-53.

Jones, Deondre'. 2019. "National Taxonomy of Exempt Entities (NTEE) Codes." Urban Institute National Center for Charitable Statistics. Accessed July 26. https://nccs.urban.org/project/national-taxonomy-exempt-entities-ntee-codes.

Karlan, Dean, and Daniel H. Wood. 2017. “The Effect of Effectiveness: Donor Response to Aid Effectiveness in a Direct Mail Fundraising Experiment." Journal of Behavioral and Experimental Economics 66: 1-8.

Keating, Elizabeth K., and Peter Frumkin. 2003. "Reengineering Nonprofit Financial Accountability: toward a More Reliable Foundation for Regulation." Public Administration Review 63 (1): 3-15.

Konrath, Sara, and Femida Handy. 2018. "The Development and Validation of the Motives to Donate Scale." Nonprofit and Voluntary Sector Quarterly 47 (2): 347-75.

Krashinsky, Michael. 1986. "Transaction Costs and a Theory of the Nonprofit Organization." In The Economics of Nonprofit Institutions, edited by Susan Rose-Ackerman. New York: Oxford University Press, 133-151.

Krashinsky, Michael. 1997. "Stakeholder Theories of the Non-profit Sector: One Cut at the Economic Literature." Voluntas 8 (2): $149-61$.

Krasteva, Silvana, and Huseyin Yildirim. 2013. "(Un)Informed Charitable Civing." Journal of Public Economics 106: 14-26.

Krasteva, Silvana, and Huseyin Yildirim. 2016. "Information, Competition, and the Quality of Charities." Journal of Public Economics 144: 6477. 
Krishnan, Ranjani, Michelle H. Yetman, and Robert ]. Yetman. 2006. “Expense Misreporting in Nonprofit Organizations." The Accounting Review 81 (2): 399-420.

Lecy, Jesse D., and Elizabeth A. M. Searing. 2015. “Anatomy of the Nonprofit Starvation Cycle: an Analysis of Falling Overhead Ratios in the Nonprofit Sector." Nonprofit and Voluntary Sector Quarterly 44 (3): 539-63. https://doi.org/10.1177/0899764014527175.

Liket, Kellie C., Marta Rey-Garcia, and Karen E. H. Maas. 2014. "Why Aren't Evaluations Working and What to Do about It: A Framework for Negotiating Meaningful Evaluation in Nonprofits." American Journal of Evaluation 35 (2): 171-88.

MacAskill, William. 2016. Doing Good Better: How Effective Alturism Can Help You Help Others, Do Work that Matters, and Make Smarter Choices about Giving Back. New York: Avery.

MacAskill, William. 2017. "Effective Altruism: An Introduction." Essays in Philsopny 18 (1): 1-5.

Malani, Anup, and Eric A. Posner. 2007. "The Case for For-Profit Charities." Virginia Law Review 93: 2017-67.

Mautz, R. K. 1989. “Not-for-Profit Financial Reporting: Another View." Journal of Accountancy 168 (2): 60-66.

Mayhew, Fred. 2012. "Aligning for Impact: the Influence of the Funder-Fundee Relationship on Evaluation Utilization." Nonprofit Management \& Leadership 23 (2): 193-217.

McConville, Danielle, and Carolyn Cordery. 2018. "Charity Performance Reporting, Regulatory Approaches and Standard-setting." Journal of Accounting and Public Policy. https://doi.org/10.1016/j.jaccpubpol.2018.07.004.

McDougle, L. 2014. "Understanding Public Awareness of Nonprofit Organizations: Exploring the Awareness-confidence Relationship." International Journal of Nonprofit and Voluntary Sector Marketing 19 (3): 187-99.

Meehan Bill, and Kimberly Jonker. November 2017. "Stanford Survey on Leadership and Management in the Nonprofit Sector." Stanford CSB Center for Social Innovation, Stanford Center on Philanthropy and Civil Society, Stanford Social Innovation Review, BoardSource, and CuideStar. Stanford, CA. https://www.gsb.stanford.edu/faculty-research/publications/survey-leadership-management-nonprofit-sector.

Meehan III, William F., and Kim Starkey Jonker. 2018. Engine of Impact: Essentials of Strategic Leadership in the Nonprofit Sector. Stanford, CA: Stanford Business Books.

Mitchell, George E. 2013. "The Construct of Organizational Effectiveness: Perspectives from Leaders of International Nonprofits in the United States." Nonprofit and Voluntary Sector Quarterly 42 (2): 322-43. https://doi.org/10.1177/0899764011434589.

Mitchell, George E. 2014. “Creating a Philanthropic Marketplace through Accounting, Disclosure, and Intermediation." Public Performance and Management Review 38 (1): 23-47.

Mitchell, Ceorge E. 2017. "Accounting for Outcomes: Monitoring and Evaluation in the Transnational NCO Sector." In In Leading and Managing in the Social Sector: Strategies for Advancing Human Dignity and Social Justice, edited by Aqeel Tirmizi, and John Vogelsang, 263-82. New York: Springer.

Mitchell, Ceorge E. 2018. “Modalities of Managerialism: the “Double Bind" of Normative and Instrumental Nonprofit Managerial Imperatives." Administration \& Society 50 (7): 1037-68. https://doi.org/10.1177/0095399716664832.

Mitchell, Ceorge E., and David Berlan. 2016. "Evaluation and Evaluative Rigor in the Nonprofit Sector." Nonprofit Management $\&$ Leadership 27 (2): 237-50. https://doi.org/10.1002/nml.21236.

Mitchell, George E., and Thad D. Calabrese. 2019. “Proverbs of Nonprofit Financial Management." American Review of Public Administration 49 (6): 649-61. https://doi.org/10.1177/0275074018770458.

Moore, Mark H. 2000. "Managing for Value: Organizational Strategy in For-Profit, Nonprofit, and Covernmental Organizations." Nonprofit and Voluntary Sector Quarterly 29 (1): 183-204.

Morariu, Johanna, Katherine Athanasiades, and Ann Emery. 2012. State of Evaluation 2012: Evaluation Practice and Capacity in the Nonprofit Sector. Innovation Network (Washington, DC).

Morariu, Johanna, Veena Pankaj, Kat Athanasiades, and Deborah Grodzicki. 2016. State of Evaluation 2016: Evaluation Practice and Capacity in the Nonprofit Sector. Innovation Network (Washington, DC).

Murray, Christopher ]. L., and Alan D. Lopez, eds. 1990. Clobal Burden of Disease, the Clobal Burden of Disease and Injury1. Cambridge, MA: Harvard University Press. https://www.hup.harvard.edu/catalog.php?isbn=9780674354487.

NCN. 2013. Investing for Impact: Indirect Costs are Essential for Success. Washington, DC: National Council of Nonprofits.

Neighbor, Hope, Josh Drake, Tom Eagle, Jessica Vandermark, Bill Wilkie, Robb Willer, Tim Durbin, Salim Haji, and Liz Horberg. 2015. Money for Good 2015: Revealing the Voice of the Donor in Philanthropic Giving. San Francisco, CA: Camber Collective. http://www.cambercollective.com/moneyforgood.

North, Douglas C. 1987. “Institutions, Transaction Costs, and Economic Growth.” Economic Inquiry 25 (3): 419-28.

North, Douglas C. 1991. “Institutions." Journal of Economic Perspectives 5 (1): 97-112.

Null, C. 2011. "Warm Clow, Information, and Inefficient Charitable Giving." Journal of Public Economics 95: 455-56.

O'Flanagan, Maisie, Jacob Harold, and Paul Brest. 2008. The Nonprofit Marketplace: Bridging the Information Cap in Philanthropy. The William and Flora Hewlett Foundation and McKinsey \& Company. https://hewlett.org/wp-content/uploads/2016/08/whitepaper.pdf.

Olson, M. 1965. The Theory of Collective Action: Public Coods and the Theory of Croups. Cambridge, MA: Harvard University Press.

Ortmann, Andreas, and Mark Schlesinger. 1997. “Trust, Repute and the Role of Non-profit Enterprise." Voluntas 8 (2): 97-119.

Ottenhoff, Bob, and Greg Ulrich. 2012. More Money for Good. CuideStar USA and Hope Consulting (Washington, DC).

Perrin, Burt. 1998. "Effective Use and Misuse of Performance Measurement." American Journal of Evaluation 19 (3): 367-79.

Prakash, Aseem, and Mary Kay Gugerty. 2010. “Trust but Verify? Voluntary Regulation Programs in the Nonprofit Sector." Regulation \& Covernance 4 (1): $22-47$.

Pratt, Jon. 2019. "The True Story of Nonprofits and Taxes." Nonprofit Quarterly, April 22. https://nonprofitquarterly.org/the-true-story-ofnonprofits-and-taxes/.

Pritchett, Lant. 2002. “It Pays to Be Ignorant: A Simple Political Economy of Rigorous Program Evaluation." Policy Reform 5 (4): $251-69$.

Rainey, H. G., and P. Steinbauer. 1999. "Calloping Elephants: Developing Elements of a Theory of Effective Covernment Organizations." Journal of Public Administration Research and Theory 9 (1): 1-32.

Reed, Ehren, and Johanna Moraiu. 2010. State of Evaluation: Evaluation Practice and Capacity in the Nonprofit Sector. Innovation Network (Washington, DC). 
Ruff, Kate. 2013. "The Role of Intermediaries in Social Accounting." In Accounting for Social Value, edited by Laurie Mook, 320-248. Buffalo: University of Toronto Press.

Ruff, Kate, and Sara Olsen. 2016. “The Next Frontier in Social Impact Measurement Isn't Measurement at All." Stanford Social Innovation Review. https://ssir.org/articles/entry/next_frontier_in_social_impact_measurement.

Salamon, Lester M. 1987. "Of Market Failure, Voluntary Failure, and Third-Party Covernment: toward a Theory of Covernment-Nonporfit Relations in the Modern Welfare State." Journal of Voluntary Action Research 16: 29-49.

Sauer, Jennifer. 2016. Listen with Your Heart, Give with Your Head: AARP Foundation 2016 Colorado Survey on Charitable Giving, AARP Foundation Elder Watch. https://doi.org/10.26419/res.00131.001.

Schlesinger, M., S. Mitchell, and B. Gray. 2004. "Restoring Public Legitimacy to the Nonprofit Sector: A Survey Experiment Using Descriptions of Nonprofit Ownership." Nonprofit and Voluntary Sector Quarterly 33: 673-710.

Schmidt, Arthur "Buzz". 2014. "Divining a Vision for Markets for Cood." In Selected Readings: Making Sense of Data and Information in the Social Sector. edited by Eric ]. Henderson, 61-81. Stanford, CA: Markets for Cood. https://digitalimpact.io/ebook/https://digitalimpact.io/wordpress/wp-content/uploads/2014/01/Markets-for-Good-SelectedReadings-eBook.pdf.

Seibel, Wolfgang. 1996. "Successful Failure: An Alternative View on Organizational Coping." American Behavioral Scientist 39 (8): $1011-24$.

Singer, Peter. 2017. The Most Cood You Can Do: How Effective Altruism Is Changing Ideas About Living Ethically. New Haven, CT: Yale University Press.

Steinberg, Richard. 1987. “Voluntary Donations and Public Expenditures in a Federalist System.” The American Economic Review 77 (1): $24-36$.

Steinberg, Richard. 1997. “Overall Evaluation of Economic Theories.” Voluntas 8 (2): 179-204.

Steinberg, Richard. 2006. "Economic Theories of Nonprofit Organizations." In The Nonprofit Sector: A Research Handbook, edited by Walter W. Powell, and Richard Steinberg, 117-39. New Haven, CT: Yale University Press.

Steinberg, Richard, and Bradford H. Gray. 1993. "“'The Role of Nonprofit Enterprise" in 1993: Hansmann Revisited." Nonprofit and Voluntary Sector Quarterly 22 (4): 297-316.

Stufflebeam, Daniel L. 2001. “Evaluation Models." New Directions for Evaluation 89: 7-98.

Sugden, R. 1984. “Reciprocity: the Supply of Public Coods through Voluntary Contributions." The Economic Journal 94 (376): $772-87$.

Tassie, Bill, Vic Murry, and Denise Bragg. 1996. "Rationality and Politics: What Really Coes on When Funders Evaluate the Performance of Fundees?" Nonprofit and Voluntary Sector Quarterly 25 (3): 347-63.

Tekula, Rebecca, and Krirsten Andersen. 2018. "The Role of Covernment, Nonprofit, and Private Facilitation of the Impact Investing Marketplace." Public Performance \& Management Review 42 (1): 142-61.

Tinkelman, Daniel. 2006. “The Decision-usefulness of Nonprofit Fundraising Ratios: Some Contrary Evidence." Journal of Accounting, Auditing, and Finance 21 (4): 441-62.

Tinkelman, Daniel, and Kamini Mankaney. 2007. "When Is Administrative Efficiency Associated with Charitable Donations?" Nonprofit and Voluntary Sector Quarterly 36 (1): 41-64.

Tremblay-Boire, Joannie, Aseem Prakash, and Mary Kay Gugerty. 2017. "Regulation by Reputation: Monitoring and Sanctioning in Nonprofit Accountability Clubs." Public Administration Review 76 (5): 712-22. https://doi.org/10.1111/puar.12539.

Twersky, Fay, and Lori Grange. 2016. A Practical Cuide to Outcome-Focused Philanthropy. Menlo Park, CA: Hewlett Foundation. https://hewlett.org/wp-content/uploads/2017/05/OFP-Guidebook-updated.pdf.

Vollmer, Jonas. 2017. “When Does Effectiveness Matter? an Experimental Investigation of Donors' Response to Effectiveness Information." Master, Business and Economics, University of Basel.

Weinstein, Michael M., and Ralph M. Bradburd. 2013. The Robin Hood Rules for Smart Giving. New York: Columbia University Press.

Weisbrod, Burton A. 1975. "Toward a Theory of the Voluntary Non-Profit Sector in a Three Sector Economy." In Altruism, Morality, and Economic Theory, edited by Edmund S. Phelps, 171-96. New York: Russell Sage Foundation.

Weisbrod, Burton A. 1988. The Nonprofit Economy. Cambridge, MA: Harvard University Press.

Weisbrod, Burton A., and Mark Schlesinger. 1986. "Public, Private, Nonprofit Ownership and the Response to Asymmetric Information: the Case of Nursing Homes." In The Economics of Nonprofit Institutions, edited by Susan Rose-Ackerman. New York: Oxford University Press, 133-151.

Wing, Kennard, and Mark A. Hager. 2004. Cetting What We Pay For: Low Overhead Limits Nonprofit Effectiveness. Urban Institute Center on Nonprofits and Philanthropy and Indiana University Center on Philanthropy. https://www.urban.org/sites/default/files/publication/57731/311044-Cetting-What-We-Pay-For.PDF.

Wright, B. E., and S. K. Pandey. 2011. “Public Organizations and Mission Valence: When Does Mission Matter?” Administration \& Society 43 (1) 22-44.

Young, Dennis R. 2000. “Alternative Models of Covernment-nonprofit Sector Relations: Theoretical and International Perspectives." Nonprofit and Voluntary Sector Quarterly 29 (1): 149-72.

Young, Dennis R. 2013. If Not for Profit, for What? Vol. Book 1. 2013 Faculty Books. Atlanta, CA: Ceorgia State University. 